\title{
ROOSTER BODY WEIGHT INFLUENCE ON THE REPRODUCTIVE PERFORMANCE OF THE BROILER PARENTS
}

\author{
V. Djermanovic ${ }^{1}$, S. Mitrovic ${ }^{1}$, V. Djekic ${ }^{2}$ \\ ${ }^{1}$ University of Belgrade, Faculty of Agriculture, Nemanjina 6, 11080 Zemun, Republic of Serbia. \\ ${ }^{2}$ Center for Small Grains, Save Kovacevic 31, 34000 Kragujevac, Republic of Serbia. \\ Corresponding author: djermanovic@agrif.bg.ac.rs \\ Original scientific paper
}

Abstract: In this research influence of the rooster body weight on reproductive performance of broiler parents was examined for Ross 308 and Cobb 500 hybrids. At the beginning of the productive cycle (24 weeks of age) for roosters Ross 308 hybrids average body weight of 3,030.00 g has been determined, while for Cobb 500 rooster average body weight was $3,045.00 \mathrm{~g}$. In the $42^{\text {nd }}$ week of age (middle of productive cycle), body weight of Ross 308 roosters was $4,306.00 \mathrm{~g}$ and 4,323.00 $\mathrm{g}$ for Cobb 500 roosters, while at the end of productive cycle in the $61^{\text {st }}$ week of age Ross 308 hybrids had average 4.908,00 g and Cobb $500 \mathrm{had} 4,918.50 \mathrm{~g}$. Determined differences in body weight of roosters $(15.00 \mathrm{~g}$, $17.00 \mathrm{~g}$ and $10.50 \mathrm{~g}$ ) in specific periods of productive cycle, as well as difference in body weight for the entire productive cycle (19.97 g) were not statistically significant $(\mathrm{P}>0.05)$. Between rooster body weight and fertilized eggs laying intensity positive statistically significant $(\mathrm{P}<0.001 ; \mathrm{P}<0.01 ; \mathrm{P}<0.05)$ correlation coefficients were determined. Between rooster body weight and hatchability percentage of the chicks positive statistically significant $(\mathrm{P}<0.001 ; \mathrm{P}<0.01 ; \mathrm{P}<0.05)$ correlation coefficients were determined for both hybrids. However, based on correlation coefficient it has been determined that rooster body weight had positive influence on laying intensity of fertilized eggs till $58^{\text {th }}$ week of age (Ross 308) and $60^{\text {th }}$ week of age (Cobb 500), while on hatchability of chicks it had positive influence till $58^{\text {th }}$ week of age for both hybrids. parents.

Key words: roosters, body weight, reproductive performance, broiler

\section{Introduction}

Keeping and utilizing the parental flock, as well as incubating the planting eggs are highly specific and complex phases in production process. One has to bear 
in mind that average production of one broiler parent flock, planting eggs production and day old chick production in practice is a combined result of genetic potential of the breed and breeding technology as well as the result of the egg incubation technology.

Moreover, poultry reproduction is very specific biologic process. In order to hatch a chick out of fertilized egg, it is necessary to provide needed conditions for the embryo to develop and grow. Therefore, nutrition and proper breeding conditions have influence on the poultry reproductive process. Only with proper diet, chicks breeding technology and proper utilization of the parental flock the maximal hatchability, needed chick vitality, and quality of the hatched chicks will be achieved. In order to prolong production of the fertilized eggs (day old chicks production), it is necessary to keep the roosters in constant breeding condition, where special attention should be given to the body weight. Uniformity of the flock in the terms of body weight is especially significant factor in the last weeks of the production cycle.

Next to the optimal gender aspect and age of broiler parents, on egg fertility and hatchability, body weight has significant influence (Celeghini et al., 2001; McDaniel et al., 2004; Djermanovic, 2010; Djermanovic et al., 2009; Mitrovic et al., 2010). Proper hormonal functioning of the endocrine system of the laying hens and roosters is significantly dependant on the age and body development (Wilson et al., 1979; Renden and Pirson, 1982; Bramvell et al., 1996; McGary et al., 2002; Bowling, 2003). At optimal body weight and specific age, laying hens ovaries are stimulated, ripening of the egg cells is being speeded up, while for roosters better ejaculate with larger number of active, movable and vital spermatozoids is being created, it has higher volume and proper $\mathrm{pH}$ value (El Sahn, 2007; Gebriel et al., 2009; Abd El Ghany et al., 2011; Udeh et al., 2011; Makhafola et al., 2012a; Makhafola et al., 2012b; Orunmuyi et al., 2013), therefore the percent of fertilized eggs is being increased. This shows that on egg fertility and chick hatchability male and female units have equal influence. Roosters are responsible for "real" fertilization while laying hens influence the number and the chick hatchability percent from the fertilized eggs (Djermanovic, 2010; Djermanovic et al., 2009; Mitrovic et al., 2010).

Body weight of the breeding birds, next to the other factors, especially age, has direct influence on laying intensity and hatchability percent from the number of fertilized eggs. Rooster breeding value is directly conditioned with the average body weight in specific age (week of the production process). Therefore, special attention is given to the influence of the body weight of roosters on the basic reproductive indicators during the production cycle. Main aim of this research was to determine what type of influence body weight of roosters has on the laying intensity of the fertilized eggs and at the hatchability percent. 


\section{Material and Methods}

In the present research, two parental flocks of heavy hybrids Ross 308 and Cobb 500 were taken. During the production technology recommended by selection office was used. Broiler parents of both flocks were kept on the floor with deep bedding, diet; watering, airing and illumination were automatically controlled. Effective floor surface per facility was approximately $900 \mathrm{~m}^{2}$, where density of population was approximately 6 birds $/ \mathrm{m}^{2}$ of floor surface.

Researched broiler parents flocks were bred till $61^{\text {st }}$ week of age, both flocks started laying eggs at the beginning of the $22^{\text {nd }}$ week. Eggs that were laid from the $24^{\text {th }}$ week and till the end of the production cycle, were used for incubation, because at that week they were at proper minimal weight for incubation $(>50.00 \mathrm{~g})$. This shows that period of egg production (production of day old broiler chicks) lasted 38 weeks (from $24^{\text {th }}$ till $61^{\text {st }}$ week of age of broiler parents).

As starting experimental material total number of 5200 birds of both genders of Ross 308 hybrid and 5430 broiler parents of Cobb 500, bred in two separate facilities, were used. First facility was populated with 4750 q and $450 \AA$ Ross 308 hybrids, and second facility was populated with 4960 ㅇ and $470 \curvearrowright$ Cobb 500 hybrids, so that gender ration was 1:10.56 (Ross 308) and 1:10.55 (Cobb 500).

In preparation period from $21^{\text {st }}$ till $24^{\text {th }}$ week of age mortality and elimination for Ross 308 roosters was 4 units $(0.89 \%)$, and with Cobb 5003 units $(0.64 \%)$. This means that at the beginning of the use of incubation eggs, Ross 308 broiler parents had 446 roosters, and Cobb 500 had 467 roosters.

In order to control the body weight, every week body weight of 80 roosters was individually taken using random sample method (40 roosters of Ross 308 and Cobb 500 hybrids each). By this inspection uniformity of roosters of researched flocks during production cycle and the influence of rooster body weight on reproductive indicators of broiler parents was tested.

Basic data processing was conducted using usual variation - statistical methods, and testing of the differences between hybrids was done using the $\mathrm{T}$ - test. For all monitored indicators average value, random sampling error and standard deviation were calculated. Determined results were used to calculate the correlation of researched indicators per week of production by using the correlation analysis. Statistical data processing was done using Analyst Program SAS/STAT (SAS Institute, 2000).

\section{Results and Discussion}

Average values, variability and significance in weight difference of the roosters $(\mathrm{g})$ in specific periods of the production cycle and for the entire period of incubation egg production are displayed in table 1. 
Table 1. Average values, variability and significance in weight difference of the roosters (g)

\begin{tabular}{|c|c|c|c|c|c|}
\hline $\begin{array}{c}\text { Production cycle } \\
\text { period }\end{array}$ & $\begin{array}{l}\text { Weeks of age } \\
\text { (production) }\end{array}$ & Hybrid & $x_{ \pm \mathrm{SEM}}$ & $\mathrm{S}$ & $\bar{d}$ \\
\hline \multirow{2}{*}{ Beginning } & \multirow{2}{*}{$24(1)$} & Ross 308 & $3.030,00 \pm 26.23$ & 165.92 & \multirow{2}{*}{$15.00^{\mathrm{ns}}$} \\
\hline & & Cobb 500 & $3.045,00 \pm 27.84$ & 176.11 & \\
\hline \multirow{2}{*}{ Middle } & \multirow{2}{*}{$42(19)$} & Ross 308 & $4.306,00 \pm 38.33$ & 253.90 & \multirow{2}{*}{$17.00^{\mathrm{ns}}$} \\
\hline & & Cobb 500 & $4.323,00 \pm 40.26$ & 254.58 & \\
\hline \multirow{2}{*}{ End } & \multirow[b]{2}{*}{$61(38)$} & Ross 308 & $4.908,00 \pm 60.42$ & 382.17 & \multirow{2}{*}{$10.50^{\mathrm{ns}}$} \\
\hline & & Cobb 500 & $4.918,50 \pm 61.90$ & 391.52 & \\
\hline \multirow{2}{*}{$\begin{array}{l}\text { Entire production } \\
\text { cycle }\end{array}$} & \multirow{2}{*}{$61(38)$} & Ross 308 & $4.058,75 \pm 52.33$ & 322.61 & \multirow{2}{*}{$19.97^{\mathrm{ns}}$} \\
\hline & & Cobb 500 & $4.078,72 \pm 56.19$ & 346.43 & \\
\hline
\end{tabular}

Data from table 1 shows that average body weight for roosters of both researched hybrids, compared to technologic normative (www.rossbreeders.com; www.cobb-vantress.com), at the beginning of the production cycle was significantly lower, and at the end of the production cycle insignificantly lower (within the limits of the technologic normative). However, even beside mentioned deviation considering the rooster body weight, differences between researched hybrids were not statistically significant $(\mathrm{P}>0.05)$, for the specific production periods as well as for the entire usage period.

Djermanovic (2010), Djermanovic et al. (2009) and Mitrovic et al. (2010) determined similar results during the productive cycle with slightly higher body weights of the roosters. Moreover, significantly higher body weight of Ross hybrid broiler parents bred till $71^{\text {st }}$ week of age, in specific phases of productive cycle was determined by Celeghini et al. (2001): between $24^{\text {th }}$ and $27^{\text {th }}$ week of age $(3.152$ $\mathrm{kg}), 40^{\text {th }}$ and $43^{\text {rd }}$ week $(4.990 \mathrm{~kg})$, and between $60^{\text {th }}$ and $63^{\text {rd }}$ week of age $(5.333$ $\mathrm{kg})$. Slightly lower average body weight for Ross hybrid roosters $(4.27 \mathrm{~kg})$ during the middle of the production cycle (18 weeks of production) was determined by McDaniel et al. (2004).

For analyzed parent flocks, next to the determined variations for rooster body weight, with aim to have better overview of body weight influence on reproductive performance, phenotype correlation coefficients between monitored indicators were calculated (table 2).

Up to $50^{\text {th }}$ week of age for Ross 308 hybrid and $53^{\text {rd }}$ week of age for Cobb 500 parental flocks, statistically positive $(\mathrm{P}<0.001 ; \mathrm{P}<0.01 ; \mathrm{P}<0.05)$ correlation coefficient was determined between body weight and laying intensity of fertilized eggs (table 2). From the data in table 2 it is noticeable that from $51^{\text {st }}$ week of age (Ross 308 ) and $54^{\text {th }}$ week of age (Cobb 500), weak, very weak or no correlation was determined between rooster body weight and laying intensity of fertilized eggs and determined correlation was not statistically significant $(\mathrm{P}>0.05)$. 
Table 2. Phenotype correlation between rooster body weight, laying intensity (\%) of the fertilized eggs $\left(r_{1}\right)$ and hatchability $(\%)$ of the chicks from fertilized eggs $\left(r_{2}\right)$

\begin{tabular}{|c|c|c|c|c|c|c|}
\hline \multirow{2}{*}{$\begin{array}{c}\text { Weeks of } \\
\text { age } \\
\text { (production) }\end{array}$} & \multicolumn{3}{|c|}{ Ross 308} & \multicolumn{3}{|c|}{ Cobb 500} \\
\hline & $\begin{array}{c}\text { Body } \\
\text { weight, } g\end{array}$ & $\mathrm{r}_{1}$ & $\mathrm{r}_{2}$ & $\begin{array}{c}\text { Body } \\
\text { weight, } g\end{array}$ & $\mathrm{r}_{1}$ & $\mathrm{r}_{2}$ \\
\hline $41(18)$ & 4220,00 & $0,673^{* * *}$ & $0,880^{* * *}$ & 4223,00 & $0,737^{* * *}$ & $0,882^{* * *}$ \\
\hline $42(19)$ & 4306,00 & $0,642^{* *}$ & $0,859^{* * *}$ & 4323,00 & $0,704^{* * *}$ & $0,873^{* * * *}$ \\
\hline $43(20)$ & 4335,00 & $0,614^{* *}$ & $0,826^{* * *}$ & 4381,50 & $0,670^{* * *}$ & $0,863^{* * * *}$ \\
\hline $44(21)$ & 4495,00 & $0,575^{* *}$ & $0,777^{* * *}$ & 4498,00 & $0,631^{* *}$ & $0,840^{* * * *}$ \\
\hline $45(22)$ & 4495,00 & $0,539^{* *}$ & $0,735^{* * *}$ & 4493,50 & $0,599^{* *}$ & $0,809^{* * *}$ \\
\hline $46(23)$ & 4500,00 & $0,508^{* *}$ & $0,689^{* *}$ & 4523,00 & $0,570^{* *}$ & $0,768^{* * 2 *}$ \\
\hline $47(24)$ & 4507,50 & $0,475^{*}$ & $0,645^{* * *}$ & 4552,00 & $0,541^{* *}$ & $0,717^{* * *}$ \\
\hline $48(25)$ & 4546,00 & $0,443^{*}$ & $0,593^{* * *}$ & 4574,50 & $0,514^{* *}$ & $0,643^{* * * 2}$ \\
\hline $49(26)$ & 4594,00 & $0,407^{*}$ & $0,544^{* *}$ & 4602,00 & $0,486^{* *}$ & $0,560^{* *}$ \\
\hline $50(27)$ & 4599,00 & $0,381^{*}$ & $0,476^{* *}$ & 4625,35 & $0,458^{*}$ & $0,480^{* *}$ \\
\hline $51(28)$ & 4610,50 & $0,336^{\mathrm{ns}}$ & $0,420^{*}$ & 4634,00 & $0,429^{*}$ & $0,406^{*}$ \\
\hline $52(29)$ & 4645,00 & $0,298^{\mathrm{ns}}$ & $0,358^{\mathrm{ns}}$ & 4667,00 & $0,399^{*}$ & $0,345^{\mathrm{ns}}$ \\
\hline $53(30)$ & 4668,00 & $0,262^{\mathrm{ns}}$ & $0,303^{\mathrm{ns}}$ & 4680,00 & $0,369^{*}$ & $0,289^{\mathrm{ns}}$ \\
\hline $54(31)$ & 4682,00 & $0,228^{\mathrm{ns}}$ & $0,253^{\mathrm{ns}}$ & 4692,50 & $0,338^{\mathrm{ns}}$ & $0,241^{\mathrm{ns}}$ \\
\hline $55(32)$ & 4735,00 & $0,186^{\mathrm{ns}}$ & $0,193^{\mathrm{ns}}$ & 4742,50 & $0,300^{\mathrm{ns}}$ & $0,192^{\mathrm{ns}}$ \\
\hline $56(33)$ & 4750,00 & $0,133^{\mathrm{ns}}$ & $0,140^{\mathrm{ns}}$ & 4755,00 & $0,260^{\mathrm{ns}}$ & $0,149^{\mathrm{ns}}$ \\
\hline $57(34)$ & 4800,50 & $0,083^{\mathrm{ns}}$ & $0,084^{\mathrm{ns}}$ & 4807,50 & $0,213^{\mathrm{ns}}$ & $0,097^{\mathrm{ns}}$ \\
\hline $58(35)$ & 4842,50 & $0,027^{\mathrm{ns}}$ & $0,017^{\mathrm{ns}}$ & 4846,50 & $0,159^{\mathrm{ns}}$ & $0,041^{\mathrm{ns}}$ \\
\hline $59(36)$ & 4884,00 & $-0,028^{\text {ns }}$ & $-0,069^{\mathrm{ns}}$ & 4890,00 & $0,093^{\mathrm{ns}}$ & $-0,037^{\mathrm{ns}}$ \\
\hline $60(37)$ & 4902,50 & $-0,085^{\mathrm{ns}}$ & $-0,163^{\mathrm{ns}}$ & 4911,00 & $0,025^{\mathrm{ns}}$ & $-0,134^{\mathrm{ns}}$ \\
\hline $61(38)$ & 4908,00 & $-0,140^{\mathrm{ns}}$ & $-0,251^{\mathrm{ns}}$ & 4918,50 & $-0,050^{\mathrm{ns}}$ & $-0,226^{\mathrm{ns}}$ \\
\hline
\end{tabular}

However, in the last three weeks $\left(59^{\text {th }}, 60^{\text {th }}\right.$ and $\left.61^{\text {st }}\right)$ with Ross 308 , and $61^{\text {st }}$ week of age for Cobb 500 negative correlation was determined, but it wasn't statistically significant $(\mathrm{P}>0.05)$. Unlike for laying intensity of fertilized eggs, between rooster body weight and chick hatchability positive statistically significant $(\mathrm{P}<0.001 ; \mathrm{P}<0.01 ; \mathrm{P}<0.05)$ correlation was determined up to $51^{\text {st }}$ week of age for both hybrids (table 2$)$. For both parent flocks from $52^{\text {nd }}$ till $58^{\text {th }}$ week of age $\left(29^{\text {th }}\right.$ till $35^{\text {th }}$ week of production) positive phenotype correlation, between monitored indicators, was determined but it wasn't statistically significant $(\mathrm{P}>0.05)$. Moreover, in the last three weeks of production cycle, for both broiler parents flocks, rooster body weight had negative influence on hatchability of the chicks, but determined phenotype correlation between monitored indicators was not statistically significant $(\mathrm{P}>0.05)$. Based on results, it can be noted that rooster body weight had positive influence on laying intensity of fertilized eggs up to $58^{\text {th }}$ week of age for Ross 308 hybrid and up to $60^{\text {th }}$ week of age for Cobb 500 hybrid, and it had positive influence on hatchability of day old broiler chicks up to $58^{\text {th }}$ week of age for both researched parent flocks.

Djermanovic (2010) had similar results regarding the rooster body weight influence on reproductive traits in his research of the reproductive performances of 
two broiler parent flocks (Ross 308 and Cobb 500), whereas McGary et.al. (2002) had similar results with two different strains of different age (strain A - 50 weeks and strain B - 48 weeks). Similar research was conducted by Wilson et al. (1979) and Bowling (2003) where authors are pointing out that rooster fertility, due to larger number of abnormal spermatozoids, decreases with the increase of age, therefore the body weight of males decrease too. Authors determined negative correlation between growth rate and fertility of the roosters. Bowling (2003) found negative correlation $(\mathrm{r}=-0.23)$ between body weight of young $(35-45$ weeks $)$ and older (50 - 65 weeks) roosters and fertility, whereas Wilson et al. (1979) determined weak correlation $(\mathrm{r}=-0.39$ do $\mathrm{r}=0.09)$. However, El Sahn (2007), Gebriel et al. (2009), Abd El Ghany et al. (2011), Udeh et al. (2011) and Orunmuyi et al. (2013) determined positive correlation between body weight of different genotype roosters and volume, concentration of ejaculate, while Makhafola et al. (2012a) and Makhafola et al. (2012b) points out that body weight of Naked Neck roosters and Ovampo genotypes is in negative correlation with volume, concentration and $\mathrm{pH}$ value of the sperm, and for the autochthonous South African strain Potchfstroom Koekoek the correlation was positive. In the contrary of the above stated, Renden and Pirson (1982) and Bramvell et al. (1996) determined that there is no difference in fertility of the young (39 weeks) and old (65 weeks) roosters, therefore pointing out that spermatozoids retain their physiological ability to fertilize in at least two productive cycles.

\section{Conclusion}

Based on obtained results it can be concluded that average body weight for both researched hybrids, compared to technologic normative, was lower at the beginning as well as in the end of the productive cycle. However, even with variations in specific periods, differences between rooster body weight of the researched hybrids were not statistically significant $(\mathrm{P}>0.05)$.

In weekly observation, between average body weight of the roosters and laying intensity of fertilized eggs positive statistically significant $(\mathrm{P}<0.001$; $\mathrm{P}<0.01 ; \mathrm{P}<0.05)$ correlation was determined up to the $50^{\text {th }}$ week of age $\left(27^{\text {th }}\right.$ production week) for Ross 308 hybrid, and for the Cobb 500 hybrid up to the $53^{\text {rd }}$ week of age ( $27^{\text {th }}$ production week). Between rooster body weight and hatchability percent positive statistically significant $(\mathrm{P}<0.001 ; \mathrm{P}<0.01 ; \mathrm{P}<0.05)$ correlation was determined up to the $51^{\text {st }}$ week of age $\left(28^{\text {th }}\right.$ production week $)$ for both researched hybrids.

Based on obtained phenotype correlation coefficients and their significance it can be said that rooster body weight has had a significant influence on breeding ability, because in the last three weeks of the production cycle, for both flocks, between researched indicators especially egg fertilization, negative correlation coefficients were determined. This leads to the fact that with increase of body 
weight breeding ability of the roosters declines, which points out the requirement to significantly lessen the production cycle time.

\title{
Acknowledgement
}

The credit for making this research possible goes to the Ministry of Education and Science of the Republic of Serbia for sponsoring part of the study within project No TR -31033 .

\section{Uticaj telesne težine petlova na reproduktivne performanse brojlerskih roditelja}

\author{
V. Djermanovic, S. Mitrovic, V. Djekić
}

\section{Rezime}

Ispitivanje uticaja telesne težine petlova na reproduktivne performanse brojlerskih roditelja sprovedeno je kod hibrida Ross 308 i Cobb 500. Na početku proizvodnog ciklusa (24. nedelja starosti) kod hibrida Ross 308 utvrđena je prosečna telesna težina petlova $3.030,00 \mathrm{~g}$, a Cobb $5003.045,00 \mathrm{~g}$. U 42. nedelji starosti (sredina proizvodnog ciklusa) telesna težina petlova iznosila je 4.306,00 g (Ross 308) i 4.323,00 g (Cobb 500), dok je na kraju proizvodnog ciklusa (61. nedelja starosti) telesna težina petlova kod hibrida Ross 308 iznosila 4.908,00 g, a hibrida Cobb $5004.918,50 \mathrm{~g}$. Utvrđene razlike telesne težine petlova $(15.00 \mathrm{~g}$, $17.00 \mathrm{~g}$ i $10.50 \mathrm{~g}$ ) u određenim periodima proizvodnog ciklusa, kao i razlika u telesnoj težini petlova za ceo proizvodni ciklus (19.97 g), nisu bile statistički signifikantne $(\mathrm{P}>0.05)$. Između telesne težine petlova $\mathrm{i}$ intenziteta nosivosti oplođenih jaja utvrđeni su pozitivni statistički značajni $(\mathrm{P}<0.001 ; \mathrm{P}<0.01 ; \mathrm{P}<0.05)$ koeficijenti korelacije do 50. nedelje starosti kod hibrida Ross 308, odnosno 53. nedelje kod roditeljskog jata hibrida Cobb 500, a između telesne težine petlova i procenta izvodljivosti pilića utvrđeni su pozitivni statistički značajni $(\mathrm{P}<0.001$; $\mathrm{P}<0.01 ; \mathrm{P}<0.05$ ) koeficijenti korelacije do 51 . nedelje starosti kod oba ispitivana hibrida. Međutim, na osnovu koeficijenata korelacije utvrđeno je da je telesna težina petlova pozitivno uticala na intenzitet nosivosti oplođenih jaja do 58. nedelje starosti (Ross 308), tj. 60. nedelje starosti (Cobb 500), a na izvodljivost jednodnevnih brojlerskih pilića do 58. nedelje starosti kod oba ispitivana roditeljska jata. 


\section{References}

ABD EL GHANY F.A., ALM EL DEIN A.K., SOLIMAN M.M., REZZA A.M., EL-SODANY S.M. (2011): Relationship between some body measurements and fertility in males of two local strains of chickens. Egyptian Poultry Science, 32(II), 331-349.

BOWLING E.R. (2003): Sperm mobility in broiler breeders. Master of Science, Athens, The University of Georgia.

BRAMWELL R.K., McDANIEL C.D., WILSON J.L., HOWARTH B. (1996) Age effects of male and female broiler breeders on sperm penetration of the perivitelline layer overlying the germinal disc. Poult. Sci., 75: 755-762.

CELEGHINI E.C.C., ALBUQUERQUE R., ARRUDA R.P., LIMA C.G. (2001): Seminal characteristics evaluation of the male broiler breeder selected by comb development to reproduction. Braz. J. Vet. Res. Anim. Sci., v. 38, n. 4, 177-183.

DJERMANOVIC V. (2010): Phenotype variability and correlation of productive and reproductive characteristics of heavy hybrid hen lines Cobb 500 and Ross 308. $\mathrm{PhD}$ thesis, University of Belgrade, Faculty of Agriculture.

DJERMANOVIC V., MITROVIC S., DJEKIC V., RAJOVIC M., RAKIC S. (2009): Efficiency of use genetic potential of broiler poultry parents in our country. Poultry, 7/8, 29-39.

EL-SAHN A.A. (2007): Use of phenotypic traits to predict cocks fertility, 2. The ornamental and non-ornamental traits. Egyptian Poultry Science, 27, 1085-1097.

GEBRIEL G.M., KALAMAH M., EL-FIKY A., ALI A.F.A. (2009): Some factors affecting Semen quality trait in Norfa cocks. Egyptian Poultry Science, 29(11), 677-693.

MAKHAFOLA M.B., UMESIOBI D.O., MPHAPHATHI M.L., MASENYA M.B., NEDAMBALE T.L. (2012a): Characterization of Sperm Cell Motility Rate of Southern African Indigenous Cockerel Semen following Analysis by Sperm Class Analyser. Journal Animal Science Advances, 2(4), 416-424.

MAKHAFOLA M.B., UMESIOBI D.O., NEDAMBALE T.L. (2012b): Relationship between phenotypic and sperm traits of South African indigenous cockerels. International Journal of Livestock Production, Vol. 3(6), 61-65.

McDANIEL C.D., HOOD J.E., PARKER H.M. (2004): An Attempt at Alleviating Heat Stress Infertility in Male Broiler Breeder Chickens with Dietary Ascorbic Acid. International Journal of Poultry Science, 3 (9): 593-602.

McGARY S., ESTEVEZ I., BAKST M.R., POLLOCK D.L. (2002): Phenotypic Traits as Reliable Indicators of Fertility in Male Broiler Breeders. Poultry Science, 81: 102-111.

MIROVIC S., DJERMANOVIC V., RADIVOJEVIC M., RALEVIC N., OSTOJIC Dj. (2010): Possibilities of more efficient usage of genetic potential of broiler breeders. African Journal of Biotechnology, Vol. 9 (18), 2584-2594. 
ORUNMUYI M., AKANWA C.L., NWAGU B.I. (2013): Semen Quality Characteristics and Effect of Mating Ratio on Reproductive Performance of Hubbard Broiler Breeders. Journal of Agricultural Science, Vol. 5 (1), 1916-9760. RENDEN J.A., PIERSON M.L. (1982): Long-term reproductive performance of broiler breeder males selected for semen performance. Poult. Sci., 61:1214-1217. SAS INSTITUTE (2000): SAS (Statistical Analysis System). User's guide: Statistics. SAS Institute Inc. Cary, NC.

UDEH I., UGWU S.O.C., OGAGIFO N.L. (2011): Predicting Semen traits of Local and Exotic Cocks using Linear Body Measurements. Asian Journal of Animal Sciences, 5 (4): 268-276.

WILSON H.R., PIESCO N.P., MILLER E.R., NESBETH W.G. (1979): Prediction of the fertility potential of broiler breeder males. World's Poult. Sci. J., 35:95-118. www.rossbreeders.com www.cobb-vantress.com

Received 25 February 2013; accepted for publication 15 March 2013 